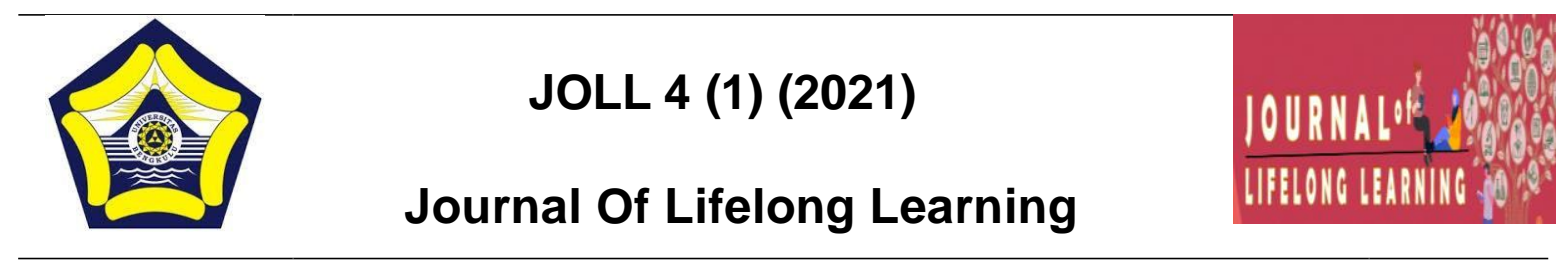

\title{
BENTUK PARTISIPASI MASYARAKAT DALAM KEGIATAN POSYANDU KASIH IBU
}

\author{
Essy Ena Lestari ${ }^{1}$, Agus Zainal Rachmat ${ }^{2}$
}

'Essy Ena Lestari, Universitas Bengkulu, Indonesia, essyenalestari17@gmail.com

${ }^{2}$ Agus Zainal, Universitas Bengkulu, Indonesia, aguszainal@unib.ac.id

\begin{abstract}
This study aims to describe the form of community participation in the activities of the Ibu Jaya Posyandu Kasih Ibu Village, Sumber Jaya Village, Kampung Melayu District, Bengkulu City. This study used a qualitative descriptive study with interview, observation, and documentation methods. Checking the validity of the data used triangulation, namely time triangulation, subject triangulation, and technical triangulation. The results showed that there are forms of community participation in the activities of Posyandu Kasih Ibu, Sumber Jaya Village, Kampung Melayu District, Bengkulu City, namely: 1) Money participation. Community voluntary contributions for mutual assistance during maternal and child health activities (KIA), and diarrhea prevention and control activities at the Kasih Ibu Posyandu, 2) Participation of personnel. The community helps cadres in the Kasih Ibu Posyandu, for the purpose of providing maternal and child health services. For example, helping weigh the baby, cleaning up the Posyandu after the activity, etc., and 3) Participation skills. The community is skilled at making ORS, which are given to mothers and children in the prevention and control of diarrhea at the Kasih Ibu Posyandu.
\end{abstract}

Keywords: Participation, community and Posyandu

C2021 DeptofNonformalEducationUNIB ISSN : 2715-9809

\footnotetext{
$\square$ Addresscorrespondence:

Jl.W.R.Supratman,KandangLimun,MuaraBangkaHulu, KotaBengkulu,Bengkulu3837
} 


\section{PENDAHULUAN}

Posyandu merupakan salah satu bentuk Upaya Kesehatan Bersumber Daya Masyarakat (UKBM) yang dikelola dan diselenggarakan dari, oleh, untuk dan bersama masyarakat dalam penyelenggaraan pembangunan kesehatan, guna membedayakan masyarakat dan memberikan kemudahan kepada masyarakat dalam memperoleh pelayanan kesehatan sasar utnuk mempercepat penurunan angaka kematian ibu dan bayi. UKBM adalah wahana pemberdayaan masyarakat yang dibentuk atas dasar kebutuhan masyarakat, dikelola, oleh, untuk dan bersama masyarakat. Pelayanan kesehatan yang dilaksanakan di Posyandu adalah Kesehatan Ibu dan Anak (KIA), Keluarga Berencana (KB), Imunisasi, Gizi dan Penanggulangan Diare (DepKes RI 2006:11)

Posyandu juga dapat disebut sebagai satuan pendidikan nonformal di mana posyandu juga merupakan kelompok belajar dalam masyarakat, kelompok belajar tersebut dapat terjadi pada saat kegiatan posyandu berlangsung, kader posyandu disebut sebagai fasilitator dan anggota posyandu sebagai peserta didik, fasilitator berfungsi sebagai pemberi motivasi, petugas penyuluhan dan pelayanan kesehatan.

Menurut Sudjana (2000:22-23) pendidikan nonformal ialah setiap kegiatan terorganisasi dan sistematis, di luar sistem persekolahan yang mapan, dilakukan secara mandiri atau merupakan bagian penting dari kegiatan yang lebih luas, yang sengaja dilakukan untuk melayani peserta didik tertentu di dalam mencapai tujuan pembelajarannya.

Dalam kamus besar Bahasa Indonesia, partisipasi adalah prihal turut berperan serta suatu kegiatan atau keikutsertaan atau peran serta. Menurut Dr. Made Pidarta dalam Astuti,
Siti Irene (2011:50) partisipasi adalah pelibatan seseorang atau beberapa orang dalam suatu kegiatan. Keterlibatan dapat berupa keterlibatan mental dan emosi serta fisik dalam menggunakan segala kemampuan yang dimilikinya (berinisiatif) dalam segala kegiatan yang dilaksanakan serta mendukung pencapaian tujuan dan tanggung jawab atas segala keterlibatan.

Partisipasi masyarakat dalam kegiatan posyandu merupakan langka awal yang dapat dilakukan untuk mengikutsertakan anggota masyarakat untuk ikut serta dalam proses pemberdayaan masyarakat di bidang kesehatan dengan tujuan dapat menunjang serta meningkatkan derajat kesehatan masyarakat.

Menurut Huraerah, Abu (2011:116) bentuk partisipasi adalah macamnya sumbangan yang diberikan seseorang, kelompok, atau masyarakat yang berpartisipasi. Sehubungan dengan penjelasan tersebut, menurut Hamijoyo dan Iskandar, yang dikutip Pasaribu dan Simanjutak (1986:349) dalam Huraerah, Abu (2011:116) bentuk-bentuk partisipasi masyarakat dapat dilihat sebagai berikut:

a. Partisipasi buah pikiran, yang diberikan partisipan dalam anjang sono, pertemuan atau rapat.

b. Partisipasi tenaga, yang diberikan partisipan dalam berbagai kegiatan untuk perbaikan atau pembangunan desa, pertolongan bagi orang lain, dan sebagainya.

c. Partisipasi hara benda, yang diberikan orang dalam berbagai kegiatan untuk perbaikan atau pembangunan desa, pertolongan bagi orang lain, dan sebagainya.

d. Partisipasi keterampilan dan kemahiran, yang diberikan orang untuk mendorong aneka ragam bentuk usaha atau industry. 
e. Partisipasi sosial, yang diberikan orang sebagai tanda keguyuban. Misalnya turut arisan, koperasi, layad (dalam peristiwa kematian), kondangan (dalam peristiwa pernikahan), nyambungan, mulang sambung.

Sementara itu, Sulaiman (1985:23) dalam Huraerah, Abu (2011:117) membagi bentuk-bentuk partisipasi social ke dalam lima macam, yaitu:

a) Partisipasi langsung dalam kegiatan bersama secara fisik dan tatap muka.

b) Partisipasi dalam bentuk iuran uang atau barang dalam kegiatan partisipatori, dana, dan sarana sebaiknya datang dari dalam masyarakat sendiri. Kalaupun terpaksa diperlukan dari luar, hanya bersifat sementara dan hanya sebagai umpan.

c) Partisipasi dalam bentuk dukungan.

d) Partisipasi dalam proses pengambilan keputusan.

e) Partisipasi representif dengan memberikan kepercayaan dan mandate kepala wakilwakil yang duduk dalam organisasi atau panitia.

Berdasarkan studi yang dilakukan peneliti di Posyandu Kasih Ibu pada hari senin 2 Maret 2020 dan hari selasa 22 September 2020 didapat data bahwa Posyandu Kasih Ibu adalah Posyandu yang berdiri pada tahun 2005, yang terletak di samping rumah warga yaitu rumah Mbah Sulami, yang beralamat di Kelurahan Sumber Jaya Kecamatan Kampung Melayu Kota Bengkulu, serta tempatnya bersih dan layak digunakan. Posyandu Kasih Ibu ini melakukan kegiatan posyandu setiap tanggal 22 dan apabila tanggal 22 tanggal merah maka kegiatan posyandu dilakukan pada tanggal 23.

Posyandu Kasih Ibu merupakan Posyandu yang berpusat di Poskesmas Padang Serai Kota
Bengkulu. Dimana Posyandu yang berpusat di Poskesmas Padang Serai ini terdapat 4 Posyandu, yaitu: Posyandu Kasih Ibu, Posyandu Melati, Posyandu Kuntum Mekar, dan Posyandu Karya Bahari. Dari keempat Posyandu yang berpusat di Poskesmas Padang Serai, Posyandu Kasi Ibu paling unggul karena Posyandu Kasih Ibu kadernya lebih dari 5 orang yaitu 9 orang, Posyandu Kasi Ibu ini telah memproleh Juara 1 Posyandu tingkat Kota Bengkulu tahun 2017, pendukung 10 program PKK, dan jumlah kunjungan masyarakat ke Posyandu Kasih Ibu lebih banyak daripada ketiga Posyandu lainnya, yaitu berjumlah 34100 orang/bulan. Selain itu, pada kegiatan Posyandu Kasi Ibu ini masyarakat Kelurahan Sumber Jaya Kecamatan Kampung Melayu Kota Bengkulu sangat berpartisipasi dalam kegiatan posyandu, masyarakat juga saling mengingatkan satu sama lain untuk berpartisipasi dalam kegiatan posyandu, jarak rumah masyarakat dengan posyandu dekat dan pelayanan posyandu ini dilakukan secara gratis.

Dari data yang dipaparkan diatas, maka peneliti tertatik untuk melakukan penelitian mendalam mengenai "Bentuk Partisipasi Maysrakat Dalam Kegiatan Posyandu Kasih Ibu"

\section{METODE}

Penelitian ini dilakukan di Posyandu Kasih Ibu Kelurahan Sumber Jaya Kecamatan Kampung Melayu Kota Bengkulu. Metode yang digunakan peneliti pada penelitian ini adalah penelitian deskripsti kualitatif. Penelitian kualitatif adalah penelitian yang berlandaskan pada filsafat postpositivisme, digunakan untuk meneliti pada kondisi obyek yang alamiah, (sebagai lawannya adalah eksperimen) dimana peneliti adalah sebagai instrument kunci, teknik pengumpulan data dilakukan secara triangulasi (gabungan), 
analisis data bersifat induktif/kualitatif, dan hasil penelitian kualitatif lebih menekankan makna dari pada generalisasi (Sugiyono, 2013:9).

Penelitian ini dilakukan dalam waktu 3 minggu yaitu dari tanggal 10 Februari s/d 03 Maret 2021. Informan dalam penelitian ini berjumlah 4 (empat) orang dengan pertimbangan bahwa mereka dapat memberikan informasi mengenai partisipasi masyarakat dalam kegiatan Posyandu Kasih Ibu Kelurahan Sumber Jaya Kecamatan Kampung Melayu Kota Bengkulu. Keempat informan ini dipilih karena mereka telah mewakili informasi yang dibutuhkan. Adapun informan penelitian ini yaitu: Mbah Sulami selaku Ketua Kader Posyandu Kasih Ibu, Ibu Hasnawati selaku Ibu RW, Ibu Isnafuah selaku kader Posyandu Kasih Ibu yang bertugas dibagian pencatatan, dan Ibu Sumariah selaku anggota Posyandu Kasih Ibu dalam kegiatan Keluarga Berencana (KB).

Teknik pengumpulan data yang digunakan dalam penelitian ini adalah melalui wawancara, observasi, dan dokumentasi. Sedangkan untuk memastikan dan menganalisis data atau informasi yang telah didapat, maka peneliti melakukan terianggulasi berupa trianggulasi subjek, trianggulasi waktu, dan trianggulasi teknik.

\section{HASIL DAN PEMBAHASAN}

Posyandu Kasih Ibu adalah Posyandu yang berdiri pada tahun 2005, yang terletak di samping rumah warga yaitu rumah Mbah Sulami, yang beralamat di Kelurahan Sumber Jaya Kecamatan Kampung Melayu Kota Bengkulu, serta tempatnya bersih dan layak digunakan. Posyandu Kasih Ibu melakukan kegiatan posyandu setiap tanggal 22 dan apabila tanggal 22 tanggal merah maka kegiatan posyandu dilakukan pada tanggal 23, dan Posyandu Kasih Ibu ini berpusat di Puskesmas Padang Serai. Wilaya kerja Posyandu Kasih Ibu ini terdiri dari 2 RW dan 9 RT, yaitu: RW 1 yang terdiri dari RT 2, 3, 4, 5, 20 dan 25, dan RW 5 yang terdiri dari RT 6, 7 dan 17.

Berdasarkan dengan hasil penelitian yang telah dilakukan peneliti dengan teknik wawancara, observasi, dan dokumentasi, maka didapatkan hasil sebagai berikut: Bentuk partisipasi masyarakat dalam kegiatan Posyandu Kasih Ibu, yaitu:

1) Partisipasin uang

Masyarakat iuran sukarela untuk kebutuhan gotong royong pada saat kegiatan kesehatan Ibu dan Anak (KIA), dan kegiatan pencegahan dan penanggulangan diare di Posyandu Kasih Ibu.

2) Partisipasi tenaga

Masyarakat membantu kader dalam kegiatan Posyandu Kasih Ibu, guna untuk pelayanan kesehatan Ibu dan Anak. Misalnya membantu menimbang Bayi, beres-beres tempat Posyandu setelah kegiatan, dan lain-lain

3) Partisipasi keterampilan

Masyarakat terampil membuat oralit, yang diberikan kepada Ibu dan Anak dalam kegiatan pencegahan dan penanggulangan Diare di Posyandu Kasih Ibu.

\section{SIMPULAN}

Posyandu Kasih Ibu adalah Posyandu yang berdiri pada tahun 2005, yang terletak di samping rumah warga yaitu rumah Mbah Sulami, yang beralamat di Kelurahan Sumber Jaya Kecamatan Kampung Melayu Kota Bengkulu, serta tempatnya bersih dan layak digunakan. Posyandu Kasih Ibu melakukan kegiatan posyandu setiap tanggal 22 dan apabila tanggal 22 tanggal merah maka kegiatan posyandu dilakukan pada tanggal 23, dan Posyandu Kasih Ibu ini berpusat di Puskesmas Padang Serai. Wilaya kerja Posyandu Kasih Ibu ini terdiri dari $2 \mathrm{RW}$ dan 9 RT, yaitu: RW 1 
yang terdiri dari RT 2, 3, 4, 5, 20 dan 25 , dan RW 5 yang terdiri dari RT 6, 7 dan 17.

Bentuk partisipasi masyarakat dalam kegiatan Posyandu Kasih Ibu Kelurahan Sumber Jaya Kecamatan Kampung Melayu Kota Bengkulu yaitu:

1. Partisipasin uang Masyarakat iuran sukarela untuk kebutuhan gotong royong pada saat kegiatan kesehatan Ibu dan Anak (KIA), dan kegiatan pencegahan dan penanggulangan diare di Posyandu Kasih Ibu.

2. Partisipasi tenaga Masyarakat membantu kader dalam kegiatan Posyandu Kasih Ibu, guna untuk pelayanan kesehatan Ibu dan Anak. Misalnya membantu menimbang Bayi, beres-beres tempat Posyandu setelah kegiatan, dan lain-lain

3. Partisipasi keterampilan

Masyarakat terampil membuat oralit, yang diberikan kepada Ibu dan Anak dalam kegiatan pencegahan dan penanggulangan Diare di Posyandu Kasih Ibu.

\section{DAFTAR PUSTAKA}

Astute, Siti Irene, 2011. Desentralisasi Dan Partisipasi Masyarakat Dalam Pendidikan. Yogyakarta: Pustaka Pelajar

DepKes RI, 2006. Pedoman Umum Pengelolaan Posyandu. Jakarta: DepKes

Huraerah, Abu, 2011. Pengorganisasian \& Pengembangan Masyarakat Model \&Strategi Pembangunan Berbasis Kerakyatan. Bandung: Buku Pendidikan - Anggota IKAPI

Sudjana, 2000. Pendidikan Luar Sekolah. Bandung: Falah Production
Sugiyono, 2015. Memahami Penelitian Kualitatip. Bandung: ALFABETA, $\mathrm{cV}$

Sugiyono, 2013. Metode Penelitian Kuantitatif Kualitatif Dan R\&D. Bandung: ALFABETA, cv 